\title{
A Community Based Collaborative Research Model to Fight Coronavirus Disease (COVID-19). A Report on Nairobi, Kenya COVD-19 Efforts
}

\author{
Samson Chama ${ }^{1 *}$, Enouce Ndeche ${ }^{2}$ \\ ${ }^{1}$ Department of Social Work, Alabama A \& M University, Huntsville. \\ 2 VAP Program Director, Westlands, Nairobi, Kenya. \\ *Corresponding author: Samson Chama, Department of Social Work, Alabama A \& M University, Huntsville. \\ Received Date: May 01, 2021; Accepted Date: May 05, 2021; Published Date: May 12,2021 \\ Citation: Samson Chama, Enouce Ndeche, (2021). A Community Based Collaborative Research Model to Fight Coronavirus Disease (COVID-19). \\ A Report on Nairobi, Kenya COVD-19 Efforts. J Clinical Research and Reports, 7(5); DOI:10.31579/2690-1919/165
}

Copyright: (C) 2021, Samson Chama. This is an open access article distributed under the Creative Commons Attribution License, which permits unrestricted use, distribution, and reproduction in any medium, provided the original work is properly cited.

\begin{abstract}
:
Today nearly almost every part of the world has been impacted by the corona virus COVID-19 pandemic. COVID-19 has been unrelenting in its impact as thousands and thousands of people have died from its infections and resulting complications. Some countries have experienced severe effects of the virus than others. However, in both situations the virus has been vicious and many of those who have recovered and survivedits infections have testified of how deadly this virus is. In the wake of this pandemic nations around the world have taken measures to curb its impact and spread in communities and societies. Preventative measures taken have disrupted in most cases schools and the workforce with many people being forced to work remotely from their homes and with schools going virtual. However, progress in fighting this virus is in the offing as promising vaccines are on the horizon. This paper discusses a preliminary intervention research project whose goal is to mitigate the impact of COVID-19 in Nairobi, Kenya. Results of this study may have promise of being replicated in other partsof Africa affected by this pandemic.
\end{abstract}

Key words: COVID-19, virus, replicate, pandemic; WHO; pneumonia; VAP; RED Cap system

\section{Introduction}

The first cases of COVID-19 pneumonia were identified in Wuhan City, China, in December 2019. In January 2020, a novel coronavirus, known as SARS-CoV-2, was identified as the cause of this outbreak. The virus, and the human disease it causes, have evolved into a global pandemic. As of April 29, 2020, according to the World Health Organization, cases have been confirmed in 213 countries, areas, or territories, with 3,090,445 confirmed cases so far, and217,769 confirmed deaths [3].

The proportion of individuals who die after being infected has been estimated to range between 0.5 to $6 \%$ or higher, making it many times more deadly than pneumonia (case fatality rate of $0.1 \%$ ). The virus is spread by respiratory droplets, and is highly infectious due to a lack of immunity in the human population. These factors make it especially dangerous in crowded areas where it can spread extremely quickly. In the absence of effective treatment or vaccine, theonly strategy available to public health workers is protective gear such as masks and gloves, and "social distancing," in which people keep at least 3.9 feet away from others (as in Kenya) and, 6 feet away from others as in the United States, in order to limit possible exposure to infected respiratory droplets [7]. Diagnostic tests showing whether someone is currently infected, and serologic tests indicating whether someone may have been exposed before and mounted an immune response, are being developed and deployed as quickly as possible.

The COVID-19 pandemic was confirmed to have spread to Africa on 14 February, 2020. The first confirmed case was in Egypt. In sub-Saharan Africa the first confirmed case of COVID-19 occurred in Nigeria. Although infections have risen and continue to grow, early and swift action by many African countries in the region has slowed down the spread of the virus. Even before the virus could hit the region, several countries, in collaboration with the World Health Organization (WHO), were already upping COVID-19 prevention and detection through measures such as airport screenings and reinforcing response preparedness [6]. WHO has also been supporting African countries to strengthen key measures including testing and treatment as well as health worker training?

Most of the identified imported cases have arrived from Europe and the United States rather than directly from China where hence the virus originated. However, it is believed that there is widespread underreporting in many African countries with less developed healthcare systems. Further, experts have worried about increasing cases of COVID19 in Africa, because many of the healthcare systems on the continent are inadequate, having problems such as lack ofequipment, lack of funding, insufficient training of healthcare workers, and inefficient data transmission [4]. Initially, it was feared that the pandemic could be difficult to keep under control in Africa, and could cause huge economic 
problems if it spread widely. However, what is transpiring is different because of the solid preventative measures implemented to combat COVID-19 in many African countries. As of April 18, 2020, the supply of ventilators has been low in much of Africa. Only 41 countries have only 2,000 ventilators between them, and 10 countries have no ventilators at all. In some cases even basic supplies like soap and water are subject to shortages in parts of the continent [2].

\section{Research Collaborative Approach by Vijama Amani Pamoja (VAP)}

To this end innovative and pragmatic approaches are critically needed to improve monitoring for symptoms, and referral to testing centers for individuals who may have been exposed to SARS-CoV-2. As efforts to increase testing capacity are made, there is need to simultaneously find effective ways of identifying individuals who may have been infected, andlink them with testing resources in order to confirm infected cases, conduct contact tracing, andcontrol the epidemic. Vijama Amani Pamoja is a succesful communitry based organization in Nairobi, Kenya. Its programmes and aims are to encourage a healthy, active lifestyles through football for young people and support them with future skills for life. To address the impact of COVID in Nairobi VAP and its partner have designed innovative approaches to collect criticaldata on symptoms, social distancing and other behaviors [1].

They are also responding to governmental policies and the role of poverty, gender, fertility, and work as predictors of COVID-19 risk and symptomatology. As they collect these data, VAP will be able to disseminate accurate information about the pandemic into high-risk communities, and will be able to refer symptomatic individuals for COVID-19 testing [5]. This innovative approach is data driven and is pragmatic with potential for replication in many countries of sub-Sahara Africa. The approach highlights important elements that are crucial to its success.

\subsection{Method}

The first element involves are project aims which must be clear and targated. To this endVAP has several aims and, aim one will involve developing an online questionnaire, accessible as a public survey, to collect detailed data on the current status of the pandemic (symptomatology, severity, and test results) as well as its risk factors and sequelae (poverty, fertility, social distancing, impact on work). VAP will implement this survey in representative samples of slum residents in Nairobi ( $\mathrm{n}=800$ from 4 slums), and more wealthy Nairobi residents(n=160 from 4 wealthy areas). In addition, they will advertise the questionnaire as a public survey, targeting paid media and other platforms all around Kenya. The research team anticipates collecting over 10,000 respondents to the public survey. During specific aim two the research team will conduct statistical analyses to determine prevalence of mild and severe symptoms in different areas, to inform targeted interventions aimed at preventing COVID-19 spread, and mitigating its effects in high risk communities. The team will focus in particular on the role of gender and fertility in impacting work status and risk for COVID-19.

In addition, VAP and its project partner will host a platform for the RED Cap system which serves as a secure data management system, and offers both password-protected dataentry, and a public survey function. They will employ both these strategies in a multi-pronged approach to characterizing the current state of the COVID-19 pandemic: first by conducting managed data entry in systematic and representative population samples in Nairobi, and second by advertising a public link to the survey that may be filled out by individuals anywhere in Kenya, or indeed in any other country although the target residents of Kenya in the current project.

\subsection{Data collection model}

Under the first data collection model with systematic sampling, VAP personnel will takea targeted and representative approach to sampling 200 residents from each of four high-risk, low-income slum areas (slum total $\mathrm{n}=800$ ) around Nairobi, Kenya. VAP has many years of extensive experience working in slum areas around Nairobi. The will also obtain representative data recruiting 40 residents from each of four different wealthier neighborhoods in Nairobi (wealthy total $n=160$ ). At the same time, the team will advertise public links to the survey across Kenya, through paid media across the country (TV, radio, newspapers, magazines), aswell as unpaid platforms (social media, word-of-mouth, links to the survey on VAP websites). For the public survey, they will target data collection from 10,000 respondents from across Kenya, collecting data on their location in addition to other factors listed above. In all cases, the team will provide accurate information for referral to testing and care for symptomatic individuals who may be infected with SARS-CoV-2.

In this crucial project the VAP team will be able to obtain estimates of symptom prevalence, severity of symptoms, and the roles of gender, fertility, and poverty. Through the representative sampling in Nairobi, the team will be able to address questions directly relevant topoverty and work. They will also evaluate the role of gender and fertility, impact of policy recommendations, social distancing, and access to COVID-19 testing and care, the changing landscape of work and employment with COVID-19. Through the national public survey sampling, VAP and its partner anticipate being able to characterize geospatial variation in symptom severity, spread of the infection, and response to policy recommendation. In addition, the national sample will allow the team to conduct wider-scale analyses of the research hypotheses. The national sample, while expected to be much larger than the representative Nairobi sample, will be somewhat limited in the likely response of individuals with greateraccess to the internet and/or greater media exposure and motivation to initiate completion of the public survey.

Results of this project will be immediately relevant to policy makers and public health officials in Kenya as they work to understand and respond to the ongoing COVID-19 pandemic.

\section{Community Based Collaborative Research Model Results and Lessons}

This project is intended to reduce the spread of COVID - 19 in Kenya as well as to createmore awareness around this dangerous and unpredictable virus. The model has potential to provide useful lessons that might be replicated in other sub-Saharan countries including the developed countries. Project lessons include the following:

1. COVID-19 is a serious threat to the well-being of every person in any country.

2. More research studies using a collaborative approach are need to discover best waysof addressing COVID-19.

3. Community mobilization and partnering is key to reaching a high number of people.

4. Community slums and other poor neighborhoods can benefit a lot from this type ofresearch model.

5. All key players and partners such as public health officials, professionals, communitymembers, government leaders, private sector, and various institutions should be involved in this type of project.

6. Research project components such sample size may differ from context to context butthe overall impact should be the same.

\section{References}

1. Agyeman, A. A., Laar, A., \& Ofori-Asenso, R. (2020). Will 
COVID-19 be a litmus testfor post-Ebola sub-Saharan Africa? Journal of Medical Virology.

2. El-Sadr, W. M., \& Justman, J. (2020). Africa in the Path of Covid19. New EnglandJournal of Medicine.

3. Gilbert, M., Pullano, G., Pinotti, F., Valdano, E., Poletto, C., Boëlle, P. Y. \& Gutierrez, B. (2020). Preparedness and vulnerability of African countries against importations ofCOVID19: a modelling study. The Lancet, 395(10227), 871-877.

4. Hopman, J., Allegranzi, B., \& Mehtar, S. (2020). Managing COVID-19 in low-andmiddle-income countries. Jama, 323(16), 1549-1550.
5. Maffioli, E. M. (2020). How Is the World Responding to the Novel Coronavirus Disease (COVID-19) Compared with the 2014 West African Ebola Epidemic? The Importance of China as a Player in the Global Economy. The American Journal of Tropical Medicine and Hygiene, 102(5), 924-925.

6. Nachega, J. B., Seydi, M., \& Zumla, A. (2020). The late arrival of COVID-19 in Africa-mitigating pan-continental spread. Clin Infect Dis.

7. Velavan, T. P., \& Meyer, C. G. (2020). The COVID-19 epidemic. Tropical Medicine \&International health, 25(3), 278.
This work is licensed under Creative Commons Attribution 4.0 License

\section{To Submit Your Article Click Here: Submit Manuscript}

DOI: $10.31579 / 2690-1919 / 165$
Ready to submit your research? Choose Auctores and benefit from:

* fast, convenient online submission

* rigorous peer review by experienced research in your field

* rapid publication on acceptance

* authors retain copyrights

* unique DOI for all articles

* immediate, unrestricted online access

At Auctores, research is always in progress.

Learn more www.auctoresonline.org/journals/journal-of-clinicalresearch-and-reports 